\title{
The Higher Education Dimension in East Asian Regionalism: A Two-tier Analysis of International Co-authorship Patterns in the ASEAN Plus Three
}

\author{
Oliver Gill
}

\author{
University College London
}

\begin{abstract}
The AUN and ASEAN+3 UNet have both sought to promote the development of a distinct higher education research community within Southeast Asia and East Asia, respectively. The purpose of this paper is two-fold. Firstly, it aims to assess the success of these organisations in delivering against this aim, reviewed against inter-regional comparators. Secondly, the paper undertakes an assessment of which countries (if any) might be predominant in driving this agenda forward, at the intra-regional level. In both levels of the investigation, a statistical analysis of changes in international co-authorship patterns across time is utilised as the means of assessing the question at hand. In accordance with the paper's core hypotheses, the findings indicate broad fulfilment of the $A U N$ and ASEAN+3 UNet's objectives, although it seems that efforts directed at building an East Asian research community have been comparatively more successful than those directed specifically at Southeast Asia. It is also found that, in a relative sense, South Korea is acting as a principal locus for higher educational regionalisation. The paper concludes by considering the implications of the analysis for East Asian higher education regionalism, with the contention being that the establishment of the aforementioned research communities provides a robust basis for the development of more formal integrative measures.
\end{abstract}

Key words: international co-authorship, higher education regionalism, higher education regionalisation, ASEAN University Network (AUN), ASEAN+3 University Network (ASEAN+3 UNet), Southeast Asian Ministers of Education Organisation (SEAMEO)

\section{Introduction}

Recent developments in the global system of higher education have seen a significant increase in the degree of crossborder interaction, such that '[c]ooperation, international exchange and integration among institutions of higher education have become the new norm' (Feuer \& Hornidge, 2015, p.327).
This international dimension in higher education manifests itself in many forms, noteworthy amongst which is a growing emphasis on higher education regionalism. This paper focusses on the evolution of collaborative networks within East Asia in the form of the Association of Southeast Asian Nations (ASEAN) Plus Three (ASEAN+3) grouping of nations. The purpose is to 
assess the progress of higher education regionalism in East Asia, with an emphasis on the question of whether the stated aim of developing a definable research community among ASEAN+3 member states is being realised and, if so, which countries are driving this agenda forward. In doing so, the ambition is to fill an identifiable gap in the literature; not only has ASEAN education been an 'under-researched topic' (Zeng, Adams \& Gibbs 2013, p.324) but, additionally, the extant research tends to focus on an analysis of regional initiatives at the intergovernmental level, whilst being notably sparse in relation to whether these initiatives are having the desired integrative effect at the level of individual institutions. Indeed, as noted by Vögtle and Martens: 'the mere fact that these initiatives have been launched does not provide evidence that reform efforts are actually under way' (2014, p.256) and it is therefore pertinent to assess whether this is, in fact, the case.

This paper's research is based on a statistical analysis of international coauthorship patterns with respect to scholarly literature, assessed across time. The Literature Review defines the concept of higher education regionalism and the regionalisation that underpins it, with a particular focus on how these concepts have been promoted in the context of ASEAN+3. Therefrom, the outcome of interest is derived. The Methodology establishes the two-tier (inter-regional and intra-regional) statistical process and associated controls that will be utilised to assess the statistical significance of East
Asian co-authorship patterns. Finally, a review of the literature pertaining to East Asian higher education regionalism is undertaken, which grounds hypotheses that a research community should be detectable within the data and that this is likely to be driven by two competitive dynamics (Malaysia vs. Singapore / China vs. Japan). In the Analysis, the data is analysed, and the results is interpreted, with reference to the hypotheses. The Conclusion reviews the analytic output and expands on its implications for East Asian higher education regionalism.

\section{Literature Review}

To understand the significance of this paper's outcome of interest, it is necessary to make a distinction between the concepts of regionalism and regionalisation. Regionalism refers to 'those processes of regionally based co-operation and co-ordination that are self-consciously driven consequences of political activities' (Beeson, 2003, p.252). Regionalism is, then, "top-down", macro-level regional integration, as conceived and led at an intergovernmental level. In the higher education context, regionalism manifests itself in the form of formal agencies, agreements and collaborative programmes that target the harmonisation and integration of otherwise nationallybounded systems. In contrast, higher education regionalisation is 'the process of building closer collaboration and alignment among higher education actors and systems within a defined area or framework called a region' (Knight, 2012, p.19). Thus, although regionalisation has 
broadly the same integrative ends as regionalism, it is distinguished from the latter concept by virtue of its being characterised by micro-level, "bottom-up" drivers. Higher education regionalisation is, then, a process led by individual institutions (e.g. universities) partnering with other such institutions, located in different countries within the region in question.

The most significant example of higher education regionalism at present is the Bologna Process, founded by way of the 1999 Bologna Declaration, to which 48 countries in the "wider" European area are presently signatories. The core goal was establishing a European Higher Education Area (EHEA) by 2010, so as to 'increase the employment prospects and geographical mobility of European citizens; and enhance the reputation of European Higher Education globally' (Campanini, 2015, p.741) through the harmonisation of the previously diverse systems of higher education. Inter-system compatibility was to be built on six outcomes: easily readable and comparable degrees; a two-cycle system; credit transferability; student and staff mobility; cooperation in quality assurance; and a European dimension in higher education (EURYDICE, 2009).

The EHEA was realised in 2010, marking the successful fulfilment of the core objective of the Bologna Process. While the attribution to a "Bologna effect" is disputed by some (Huisman, Adelman, Hsieh, Shams \& Wilkins, 2012), the implementation of the Bologna "model" has been accompanied by an increase in the absolute number and percentage of non-EHEA students within the total EHEA student population from 1.6\% to $2.6 \%$ between 1999 and 2007 (Westerheijden, Beerkens, Cremonini, Huisman, Kehm, Kovač, Lažetić, McCoshan, Muzuraityte, Souto Otero, de Weert, Witte \& Yağci, 2010, p.67), giving rise to the perception that it has increased the competitiveness of European higher education within the global marketplace (Chao Jr., 2011). Consequently, 'the European harmonisation process is widely regarded as "the model" for other regions, which learn from the European harmonisation experience and adjust "the model" to suit their own regions' (Yavaprabhas, 2014, p.81).

Of particular relevance to this paper are the Bologna-inspired attempts to establish higher education regionalism in East Asia, which have largely centred on ASEAN. Originally founded in 1967 between Indonesia, Malaysia, Singapore, Thailand and the Philippines, the initial purpose of ASEAN was 'to promote regional peace and economic growth' (Mustajarvi \& Bouchon, 2014, p.219), against the backdrop of a recent colonial experience and the growth of communism in the region. Since that point, both the membership and scope of ASEAN has broadened, to the extent that it is now 'often viewed as one of the most successful regional organisations in the developing world' (Savage, 2011, p.219). In membership terms, ASEAN has been augmented through the addition of Brunei in 1984; Vietnam in 1995; Myanmar and 
Laos in 1997; and Cambodia in 1999, giving it a total membership of 10 Southeast Asian nations. Notable expansions in the scope of ASEAN include the 2003 ASEAN Concord II, which aims to establish a formal, tri-pillared 'ASEAN Community', as well the adoption of the ASEAN Charter in 2007, which served to provide the necessary legal and institutional framework to underpin ASEAN as a legal entity (Rattanasevee, 2014).

In terms of higher education regionalism, the key development has been the formation of the ASEAN University Network (AUN). The AUN was created in 1995, incorporating leading universities from each of the ASEAN's member states and growing in line with the growth of ASEAN itself, now comprising 30 such member institutions. The AUN provides a policy interface between ASEAN and the higher education sector and, together with the Southeast Asian Ministers of Education Organisation (SEAMEO), has led on the development of initiatives targeted at the harmonisation of higher education in the region, 'based on the four pillars of student-faculty communication, collaborative research, information sharing and ASEAN research promotion' (Sugimura, 2012a, p.89). The AUN's key achievements include the creation of ASEAN University NetworkQuality Assurance (AUN-QA) in 1998, aimed at harmonisation through raising the level of higher education in the region as a whole (Umemiya, 2008), and the ASEAN Credit Transfer System (ACTS) in 2010, which supports regional student mobility. Alongside the work of the AUN, SEAMEO's Regional Centre for Higher Education and Development (RIHED) has promoted the principle of establishing a Southeast Asian Higher Education Common Space, making explicit reference to the Bologna model as being 'the way of the future' (SEAMEO RIHED, 2009, p.12).

In tandem, ASEAN has also expanded its reach through the creation of ASEAN+3, which (in addition to the ASEAN core membership) incorporates the Northeast Asian nations of China, Japan and South Korea. ASEAN+3 emerged out of the 1997 ASEAN Summit, spurred by the need to find a collective resolution to the Asian financial crisis. Since this point, the remit of ASEAN+3 has expanded and the annual summit which serves as its core 'has developed as a comprehensive forum to discuss economic, political and security issues in the region' (Hidetaka 2005: 212). Critically, this expansion in remit has extended into higher education, marked by the formation of the ASEAN+3 University Network (ASEAN+3 UNet) in 2009, closely allied with and composed in a similar fashion to the AUN.

Although, as outlined above, the AUN and ASEAN+3 UNet have concerned themselves with activities to forge higher education regionalism, relative to the successes of Bologna, '[r]egional quality assurance, mutual recognition and harmonisation of higher education systems have not been adequately addressed' (Chao Jr., 2014, p.560). It is understood that a key reason 
for the relative lack of progress is the historically disjointed nature of the higher education community in the region and, consequently, both organisations have sought to develop what Knight (2013) has referred to as the "functional" underpinnings of regionalism. That is, both organisations have seen the need to build the capacity for regionalism by nurturing micro-level regionalisation, as evident in policy documentation, which seeks to promote:

'ASEAN regional research projects... undertaken jointly by scientists/scholars of more than one member state' (AUN, 2017).

'professional interactions and create research clusters among ASEAN+3 Universities' (ASEAN+3 UNet, 2009).

These policies are both directed at the development of a distinct research community within the region in question and confirm the view that 'regionalisation in East Asia is in progress in accordance with regionalism fostered by national governments' (Sugimura, 2012b, p.62). The relative success of these organisations in developing research communities represents our outcome of interest. For the purposes of this paper, we shall measure the relative achievement of these goals in terms of the count of international coauthorships of publications, between academics from different nations. It should be acknowledged that 'this mode of counting is only one among several possible measures of collaboration, and that... collaboration may lead to a number of outcomes of which the co-authored paper is only one' (Wagner, Park \& Leydesdorff, 2015, p.3). As such, there are limitations to this analysis that will be explored further in the Conclusion. Nevertheless, the availability of a uniform dataset over time and its directly quantifiable nature make this 'the most tangible indicator' (Jung, 2012, p.237) and therefore the one most commonly applied to measuring international scholarly collaboration, as well as higher education collaboration in general.

\section{Methodology}

The Scopus database was used to collate the data on international collaborations. Scopus is the largest abstract and citation database of peerreviewed literature, covering over 22,000 journals, across a broad range of disciplines. Searches for multi-authored papers were conducted, with each being restricted to a particular "pairing" of ASEAN+3 states and a specific year within the range of interest. An author's home nation was based on the 'Affiliation Country' recorded within the database. The number of 'document results' produced by this method was taken as the number of collaborations for the given country pairing in the year in question. A document with three or more authors from distinct nations would therefore be counted more than once within the overall dataset. As we are seeking to measure the extent of collaboration, the extra weighting provided to such articles is not problematic. These searches were performed for each year in the 1985-2015 
range, to provide a comparable amount of data 'before' and 'after' the creation of the AUN.

As there has been persistent general growth in international coauthorships across the time considered (Wagner et al. 2015), the presence of such growth among ASEAN+3 nations since the formation of the AUN/ASEAN+3 UNet would not, in itself, necessarily be indicative of an "ASEAN effect". Consequently, the analysis sought to determine whether there had been a change in the co-authorship growth rate among these countries before and after a specified year (i.e. piecewise regression). A statistically significant increase in the growth rate after the relevant driver had been initiated would, it is contended, provide evidence of its having an effect on the regionalisation process. For the AUNspecific analysis, it was determined that the effect should be measured from the first year after the establishment of the permanent secretariat in 2000. This also allowed for the fact that the last of the ASEAN states was incorporated in 1999. For the ASEAN+3 UNet-specific analysis, the effect was measured after the establishment of the body itself, in 2009. The end date of the analysis was set at 2015. The start date was set at 1985 for the AUN-specific analysis, so as to provide a balanced 'before' and 'after' dataset. As it was noted that there was a significant overall growth in collaborations since 2001, it was determined that better fitted regression coefficients for the ASEAN+3 UNet-specific 'before' growth rates could be derived by setting the start date at
2001, thereby broadly balancing the datasets in the process. The division of the analysis is summarised in Figure 1.

Figure 1. Growth Rate Pivots

\begin{tabular}{llll}
\hline Test Area & Agent & Before & After \\
\hline ASEAN & AUN & $1985-2000$ & $2001-$ \\
& & & 2015 \\
& & & \\
ASEAN+3 & ASEAN+3 & $2001-2009$ & $2010-$ \\
& UNet & & 2015
\end{tabular}

The analysis was conducted over two tiers; inter-regional (tier 1) and intraregional (tier 2). The purpose of the first tier was to consider the primary question of the paper, specifically, whether regionalism was driving the creation of a research community within East Asia, within ASEAN, measured in terms of coauthorships amongst the 10 'core' ASEAN nations, and/or ASEAN +3 , measured in terms of co-authorships amongst the ASEAN bloc and the ASEAN+3 bloc (discounting collaborations within the blocs themselves). Although the performance of a t-test on the 'after' relative to the 'before' coefficient would determine whether there had been a statistically significant increase in the growth of collaborations, this would be insufficient to evidence an ASEAN effect, since extraneous factors could have influenced such an increase. In particular, since 2001 there has been a 'dramatic increase in... internationally co-authored papers... facilitated by the diffusion of Internet and email' (Iammarino \& Archibugi, 2005, p.38), which would 
directly inflate the AUN 'after' coefficient. It was decided to mitigate for such factors by analysing the ratio coefficient increase for two control cases and then applying this ratio to the 'before' coefficient of the test case, in order to provide a new hypothetical 'after' coefficient (the baseline for the null hypothesis), against which the actual 'after' coefficient could be tested for statistical significance. The model formulae for this calculation are provided in Appendix 1. The control cases selected were the collaborations for the test area (i.e. the ASEAN or ASEAN+3 bloc) with the United States and 'Other Asian' nations. The United States was selected as the first control owing to its being the predominant actor in international collaborations generally, accounting for almost $40 \%$ of all internationally coauthored papers within the National Science Board's Science \& Engineering Indicators 2016, and therefore representing a reliable 'base' control. The second control was added to account for potential confounding factors associated with other higher education regionalism drivers in the wider Asian area. Particularly noteworthy is the Brisbane Communiqué, signed by ministers of education from 27 Asia-Pacific countries in 2006. In addition to setting out "Bologna-like principles" (Rich, 2010), the Communiqué also sought the development of strong research links, teacher exchanges and partnerships' (APEM, 2006). As the majority of ASEAN+3 nations signed the Communiqué, any rise in collaborations between these countries could potentially be attributed to this process, rather than specifically East Asian regionalism. To account for this, India and Taiwan were selected to form the second control of 'Other Asian' nations. Of those countries that have been significant international collaborators, defined in the Science and Engineering Indicators 2016 as countries involved with $>1 \%$ of the total amount of international collaborations, India and Taiwan are the only countries outside of ASEAN+3 that are both likely subjects of wider Asian regionalism and signatories to the Brisbane Communiqué, making them ideally suited to this control.

On the assumption that the above research evidenced the formation of an East Asian research community, the purpose of the Tier 2 analysis was to assess whether there were any countries within the region that were contributing in an above average manner. In order to assess this, the above methodology was directly transposed. The collaboration growth rate for a given country represented the test case and the total intra-regional collaboration growth rate the control, thereby testing whether the increase in growth rate for a given country was significantly above/below the regional average.

Although current research does not directly address the question of whether a research community is materialising in East Asia, there is pertinent literature upon which hypotheses can be based. A point commonly noted is that East Asia is marked by 'immense variation... in national size and wealth, education 
resources, tertiary participation, research outputs and global connectedness' (Marginson, 2011, p.589). This diversity in higher education capacity could feasibly be an impediment to building broad collaborative networks, especially when considered alongside the fact that membership of the AUN (and the ASEAN+3 UNet) is restricted to the "top" universities in each country, making it "somewhat self-limiting" (Hawkins, 2012, p.102) in this regard. In terms of coauthorship patterns specifically, a key influencing factor 'is the location of graduate study; young researchers who have studied in another country are likely to co-author with their former professors' (Cummings, 2014, p.48). Considering that international student mobility from the East Asia region has historically been directed towards the West and, in particular, the United States (Chan, 2012; Yonezawa, Horta \& Osawa, 2016), it could be expected for this to translate into coauthorship dependence on Western institutions, thereby suppressing the development of a research community within East Asia.

However, to consider the matter purely in absolute terms would be misguided. Since we are concerned with the relative growth of co-authorship patterns, it may be that intra-East Asian collaborative networks are gaining ground, against a background of sustained Western hegemony. In this respect, it is noteworthy that ASEAN has 'helped to build a sense of common purpose and identity' (Stubbs, 2002, p.453) within East Asia (particularly Southeast
Asia). This is manifesting itself in attitudinal change at the level of higher education institutions, with a number of researchers having detected 'a distinct reorientation away from traditional centres of dominance to intra-regional collaborative networks' (Kuroda \& Passarelli, 2009, p.12). For example, in a review of the responses of 124 leading East Asian universities to the 2009 JICA-RI survey, Kuroda, Yuki \& Kang (2010, p.31) reported that 'high priority [is] placed by...[these universities] on building partnerships with other universities in the same region'. Particularly significant was the fact that Southeast Asian institutions' second most preferred partner region for cross-border higher education activities had historically been Western Europe (after Southeast Asia itself) but projected that this would shift to Northeast Asia in future. This provides a direct indication of forecast (positive) trends with respect to ASEAN+3 higher education collaboration for the 'after' period within this paper's analysis. This is supported by student mobility data (UNESCO, 2010), with the growth rate in East Asian intra-regional flows significantly outstripping those directed outside of the region. This preferential shift is particularly in evidence within Southeast Asia, where eight of the ten countries now have another ASEAN state within their "top five" student destinations. For Cambodia and Laos, other Southeast Asian nations now represent the "top" international student destination (Thailand and Vietnam, respectively). In line with the aforementioned link between student mobility and co-authorship patterns, this 
preferential shift could potentially support the development of a research community in East Asia.

On the basis of the above, it is reasonable to hypothesise that, although collaboration with the West may still predominate in international coauthorship patterns, we should expect to see the development of a research community within East Asia, the relative growth in which should significantly exceed inter-regional comparators. The Tier 1 hypotheses are defined as follows:

H1a: The 'after' coefficient for intra-ASEAN co-authorship will be significantly greater (at the 5\% significance level or better) than the hypothetical 'after' coefficient produced by both control cases.

H1b: The 'after' coefficient for 'Plus Three'ASEAN co-authorship will be significantly greater than the hypothetical 'after' coefficient produced by both control cases.

Should the development of an East Asian research community be confirmed, it is contended that this will likely have been disproportionately driven by the competitive dynamic between certain key countries to become regional "hubs" of education. At base, this competition is rooted 'in the acquisition battle for international students' (Sugimura, 2012b, p.48), within which other East Asian states represent the most accessible market. However, it is also understood that the purposeful positioning of these states at the centre of regionally integrated higher education markets is a means of strengthening their 'soft power' in the region (Mok, 2011; Yang, 2012). Understood in this sense, it is clear that it necessitates the forging of a regional network, within which the hub's influence is anchored. This, in turn, requires the development of greater international links between the hub's universities and others within the region, thereby providing a fecund setting for international coauthorship. Within Southeast Asia, the consensus is that Malaysia and Singapore have been the two states that have most openly strived to become regional hubs of education (Clark, 2012; Mok, 2011; Yap, 2012). The strategy in both countries has been to partner with high-ranked universities abroad to develop transnational degree programmes, bringing a 'branded' offer to the region. Such was the motivation behind the Singapore's Global Schoolhouse initiative (2002), as well as being a fundamental element of Malaysia's National Higher Education Strategic Plan 2020, published in 2007. Within Northeast Asia, there is a parallel competitive dynamic between China and Japan for influence within ASEAN+3. This 'Sino-Japanese rivalry' extends into higher education, with China having sought to bolster the competitiveness of its offer through intensive funding of its leading universities under Project 211 and Project 985 (Li \& Chen, 2011) and augment its 'soft power' in the region, via the proliferation of Confucian Institutes in ASEAN member states (Yang, 2012). For its part, Japan has sought to balance China's efforts by stepping up its... cooperative profile in the region' (Hund, 2003, p.411). Bringing this together, it is 
hypothesised that these competitive dynamics will have provided a locus for the development of the wider research community and that, as such, the countries in question will demonstrate a significantly greater increase in international co-authorship growth rate than the relevant regional average:

H2a: The 'after' coefficient for MalaysiaASEAN (and Singapore-ASEAN) coauthorship will be significantly greater than the hypothetical 'after' coefficient produced by the intra-ASEAN benchmark.

H2b: The 'after' coefficient for China-ASEAN (and Japan-ASEAN) co-authorship will be significantly greater than the hypothetical 'after' coefficient produced by the 'Plus Three'ASEAN benchmark

\section{Analysis}

The results of this process are presented in accordance with the two-tier methodology ${ }^{1}$.

\section{(i) Tier 1: Inter-regional}

For Southeast Asia, the number of international co-authorships between ASEAN states were totalled for each year 1985-2015 and set alongside coauthorships between ASEAN states and: (i) the United States; and (ii) 'Other Asian' nations. A piecewise regression was undertaken, with the growth rate coefficients calculated for two ('before' and 'after') time periods, using SPSS v.22.

\footnotetext{
1 The summary dataset upon which this paper's analysis was based is available on request.
}

The coefficients are presented in Table 1a, alongside the ratio coefficient increase (R) and associated hypothetical 'after' coefficients $\left(B_{1}^{0}\right)$ for ASEAN-US and ASEAN-Asia (i.e. the two controls). To explain the application of the Methodology, ' $R$ ' is calculated by dividing the relevant control's 2001-2015 coefficient by its 19852000 coefficient. ' $B_{1}^{0 \prime}$ is then produced by multiplying the 1985-2000 Intra-ASEAN coefficient by the ' $R$ ' statistic for the relevant control. Therefore, ' $B_{1}^{0 \prime}$ represents a test statistic, measuring the number of co-authorships that would be expected if the intra-ASEAN case had experienced the same level of relative collaborative growth as the two controls, between the two periods. The formulae underpinning the calculation of all test statistics are contained in Appendix 1.

The coefficients were used to perform a one-sided t-test on the null hypothesis $\left(H_{0}: B_{1}=B_{1}^{0}\right)$, where $B_{1}$ is the Intra-ASEAN 2001-2015 coefficient and $B_{1}^{0}$ was tested for both controls. As shown in Table 1a, the actual 'after' coefficient (214.46) is greater than produced by both the controls (94.79 for ASEAN-US / 205.79 for ASEAN-Asia). However, the t-tests evidence that this difference is not statistically significant with respect to the ASEAN-Asia case, due to the marginal difference between the coefficients, when factoring in the relatively large standard errors. Thus, in this instance, the $t$-value of the test $(0.187)$ is below the critical $t$ statistic for the 5\% significance level, at 54 degrees of freedom (1.674). On this basis, the t-test 'fails to reject' $H_{0}$ (i.e. the hypothesis that intra-ASEAN 
collaborative growth is not significantly greater than would be predicted by the ASEAN-Asia control). That said, in the ASEAN-US case, the difference is shown to be statistically significant at the $0.1 \%$ significance level, providing substantial grounds for differentiation in this respect. Thus, there is some evidence for an ASEAN effect bolstering international coauthorship growth and, therefore, for the hypothesis that a research community is being developed specifically in Southeast Asia (H1a).

The East Asian dataset was produced by totalling international coauthorships between the Northeast Asian nations and: (i) ASEAN states; (ii) the United States; and (iii) 'Other Asian' nations, for the period 2001-2015. The piecewise regression and coefficient calculation were of the same form as the above methodology, except for the distinction in 'pivot' date, as shown in Table 1b.

T-tests were performed in parallel with the Southeast Asian case. The actual coefficient was statistically significantly greater than that produced by both control cases, providing strong evidence in favour of the hypothesis that ASEAN+3 is supporting the development of a research community in East Asia as a whole (H1b).

\section{(ii) Tier 2: Intra-regional}

For Southeast Asia, the growth in the number of co-authorships for individual ASEAN nations (with other ASEAN nations) was benchmarked against the growth rate in the intraASEAN total.

Table 1a. ASEAN International Co-authorship Coefficients ${ }^{2}$

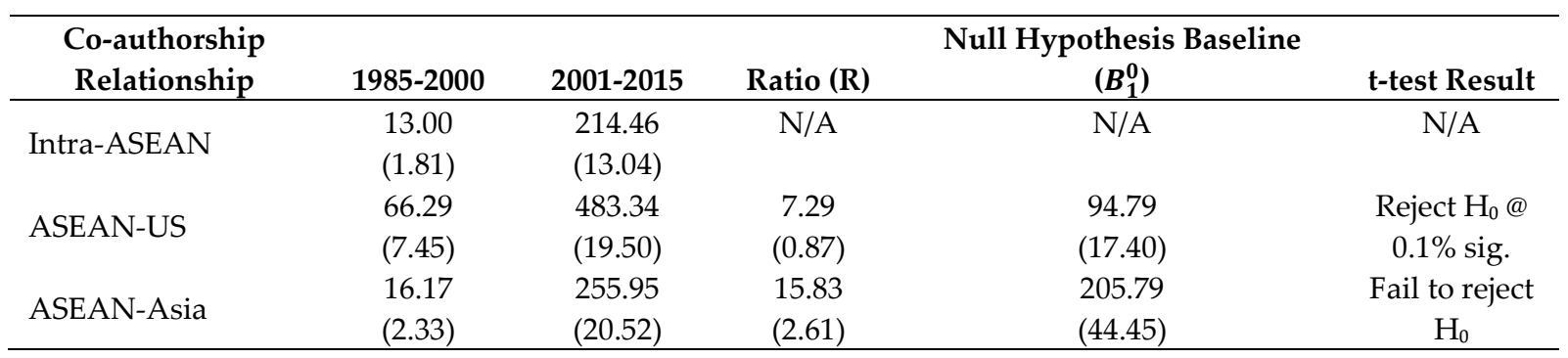

Table 1b. 'Plus Three' International Co-authorship Coefficients

\begin{tabular}{|c|c|c|c|c|c|}
\hline $\begin{array}{l}\text { Co-authorship } \\
\text { Relationship }\end{array}$ & 2001-2009 & 2010-2015 & Ratio (R) & $\begin{array}{l}\text { Null Hypothesis Baseline } \\
\left(B_{1}^{0}\right)\end{array}$ & t-test Result \\
\hline Plus Three-ASEAN & $\begin{array}{l}527.43 \\
(15.38)\end{array}$ & $\begin{array}{l}1223.00 \\
(42.75)\end{array}$ & N/A & N/A & N/A \\
\hline Plus Three- US & $\begin{array}{l}2729.65 \\
(113.90)\end{array}$ & $\begin{array}{c}5034.89 \\
(94.03)\end{array}$ & $\begin{array}{c}1.84 \\
(0.08)\end{array}$ & $\begin{array}{l}972.86 \\
(52.76)\end{array}$ & $\begin{array}{c}\text { Reject } \mathrm{H}_{0} @ \\
0.1 \% \text { sig. }\end{array}$ \\
\hline Plus Three-Asia & $\begin{array}{l}426.42 \\
(12.81) \\
\end{array}$ & $\begin{array}{l}809.06 \\
(20.18) \\
\end{array}$ & $\begin{array}{c}1.90 \\
(0.07) \\
\end{array}$ & $\begin{array}{c}1000.72 \\
(48.77) \\
\end{array}$ & $\begin{array}{c}\text { Reject } \mathrm{H}_{0} @ \\
0.5 \% \text { sig. }\end{array}$ \\
\hline
\end{tabular}

\footnotetext{
${ }^{2}$ Standard errors shown in brackets.
} 
Coefficients were calculated in a parallel fashion to the Tier 1a analysis, on the basis of the 'Tier 2' model formulae contained in Appendix 1. Thus, this involved the application of the intra-ASEAN coefficient ratio $(\mathrm{R})$ to the 'before' coefficient (1985-
2000) for each country (producing $B_{1}^{0}$ ) and using this hypothetical baseline to test the relative collaborative growth represented by the actual 'after' coefficient (2001-2015). The results are shown in Table $\mathbf{2 a}$.

Table 2a: Intra-ASEAN International Co-authorship Coefficients

\begin{tabular}{|c|c|c|c|c|c|}
\hline $\begin{array}{l}\text { Co-authorship } \\
\text { Relationship }\end{array}$ & $1985-2000$ & 2001-2015 & Ratio (R) & $\begin{array}{l}\text { Null } \\
\text { Hypothesis } \\
\text { Baseline }\left(B_{1}^{0}\right) \\
\end{array}$ & $\begin{array}{l}\text { t-test } \\
\text { Result }\end{array}$ \\
\hline $\begin{array}{l}\text { Intra- } \\
\text { ASEAN }\end{array}$ & $\begin{array}{l}13.00 \\
(1.81)\end{array}$ & $\begin{array}{l}214.46 \\
(13.04)\end{array}$ & $\begin{array}{l}16.50 \\
(2.51)\end{array}$ & N/A & $\mathrm{N} / \mathrm{A}$ \\
\hline $\begin{array}{l}\text { Brunei- } \\
\text { ASEAN }\end{array}$ & $\begin{array}{l}0.54 \\
(0.11)\end{array}$ & $\begin{array}{l}6.93 \\
(1.31)\end{array}$ & N/A & $\begin{array}{l}8.83 \\
(2.31)\end{array}$ & $\begin{array}{l}\text { Fail to } \\
\text { reject } \mathrm{H}_{0}\end{array}$ \\
\hline $\begin{array}{l}\text { Cambodia- } \\
\text { ASEAN }\end{array}$ & $\begin{array}{l}0.36 \\
(0.10)\end{array}$ & $\begin{array}{l}15.09 \\
(1.13)\end{array}$ & N/A & $\begin{array}{l}5.89 \\
(1.86)\end{array}$ & $\begin{array}{l}\text { Reject } \mathrm{H}_{0} \\
\text { @ } 0.1 \% \text { sig. }\end{array}$ \\
\hline $\begin{array}{l}\text { Indonesia- } \\
\text { ASEAN }\end{array}$ & $\begin{array}{l}3.37 \\
(0.49)\end{array}$ & $\begin{array}{l}76.31 \\
(5.96)\end{array}$ & N/A & $\begin{array}{l}55.66 \\
(11.66)\end{array}$ & $\begin{array}{l}\text { Fail to } \\
\text { reject } \mathrm{H}_{0}\end{array}$ \\
\hline Laos- & 0.46 & 10.15 & N/A & 7.57 & Fail to \\
\hline ASEAN & $(0.13)$ & $(0.98)$ & & $(2.41)$ & reject $\mathrm{H}_{0}$ \\
\hline Malaysia- & 5.19 & 114.59 & N/A & 85.59 & Fail to \\
\hline ASEAN & $(0.68)$ & $(7.27)$ & & $(17.20)$ & reject $\mathrm{H}_{0}$ \\
\hline $\begin{array}{l}\text { Myanmar- } \\
\text { ASEAN }\end{array}$ & $\begin{array}{l}0.33 \\
(0.10)\end{array}$ & $\begin{array}{l}6.82 \\
(0.99)\end{array}$ & N/A & $\begin{array}{l}5.36 \\
(1.81)\end{array}$ & $\begin{array}{l}\text { Fail to } \\
\text { reject } \mathrm{H}_{0}\end{array}$ \\
\hline $\begin{array}{l}\text { Philippines- } \\
\text { ASEAN }\end{array}$ & $\begin{array}{l}3.25 \\
(0.55)\end{array}$ & $\begin{array}{l}31.37 \\
(1.83)\end{array}$ & N/A & $\begin{array}{l}53.68 \\
(12.20)\end{array}$ & $\begin{array}{l}\text { Fail to } \\
\text { reject } \mathrm{H}_{0}\end{array}$ \\
\hline $\begin{array}{l}\text { Singapore- } \\
\text { ASEAN }\end{array}$ & $\begin{array}{l}4.29 \\
(0.63)\end{array}$ & $\begin{array}{l}61.95 \\
(3.54)\end{array}$ & N/A & $\begin{array}{l}70.84 \\
(14.95)\end{array}$ & $\begin{array}{l}\text { Fail to } \\
\text { reject } \mathrm{H}_{0}\end{array}$ \\
\hline $\begin{array}{l}\text { Thailand- } \\
\text { ASEAN }\end{array}$ & $\begin{array}{l}5.94 \\
(0.86)\end{array}$ & $\begin{array}{l}71.63 \\
(4.74)\end{array}$ & N/A & $\begin{array}{l}97.94 \\
(20.57)\end{array}$ & $\begin{array}{l}\text { Fail to } \\
\text { reject } \mathrm{H}_{0}\end{array}$ \\
\hline $\begin{array}{l}\text { Vietnam- } \\
\text { ASEAN }\end{array}$ & $\begin{array}{l}2.28 \\
(0.42)\end{array}$ & $\begin{array}{l}34.09 \\
(2.58)\end{array}$ & N/A & $\begin{array}{l}37.55 \\
(8.94)\end{array}$ & $\begin{array}{l}\text { Fail to } \\
\text { reject } \mathrm{H}_{0}\end{array}$ \\
\hline
\end{tabular}

There is an even split between those countries with above average growth rate increase (Cambodia, Indonesia, Laos, Malaysia and Myanmar) and those below this measure (Brunei, the Philippines, Singapore, Thailand and Vietnam). There are no clear patterns in this split, in terms of the scale/capacity of the higher education systems involved. Moreover, the $\mathrm{t}_{\text {-tests }}{ }^{3}$ show that the difference between the actual and hypothetical coefficients is only

\footnotetext{
${ }^{3}$ Two-sided $\mathrm{t}$-tests were performed for the second-tier analysis, since the test coefficients could be expected to be both above and below the benchmark.
} 
statistically significant for Cambodia. As Cambodia's absolute contribution to total regional co-authorships is comparatively small, this does not provide a robust basis for claims with respect to its driving collaboration in the region. The evidence contradicts the hypothesis that Southeast Asian collaboration is being driven by the competitive dynamic between Malaysia and Singapore ( $\mathrm{H} 2 \mathrm{a})$, especially as the latter's coefficient (in the 2001-2015 period) is smaller than both Indonesia and
Thailand's, by absolute measure.

For East Asia, the growth in coauthorships for each 'Plus Three' nation (with ASEAN nations) was benchmarked against the equivalent growth rate for the Plus Three-ASEAN total. The coefficient calculation paralleled the Tier $2 \mathrm{a}$ analysis, with the Plus Three-ASEAN coefficient ratio $(\mathrm{R})$ acting as the basis for calculating the hypothetical baseline $\left(B_{1}^{0}\right)$, as shown in Table 2b.

Table 2b: 'Plus Three'-ASEAN International Co-authorship Coefficients

\begin{tabular}{|c|c|c|c|c|c|}
\hline $\begin{array}{l}\text { Co-authorship } \\
\text { Relationship }\end{array}$ & 2001-2009 & 2010-2015 & Ratio (R) & $\begin{array}{c}\text { Null Hypothesi } \\
\text { Baseline }\left(B_{1}^{0}\right)\end{array}$ & t-test Result \\
\hline Plus Three-ASEAN & $\begin{array}{l}527.43 \\
(15.38)\end{array}$ & $\begin{array}{l}1223.00 \\
(42.75)\end{array}$ & $\begin{array}{c}2.32 \\
(0.11)\end{array}$ & $\mathrm{N} / \mathrm{A}$ & N/A \\
\hline China-ASEAN & $\begin{array}{l}254.03 \\
(9.50)\end{array}$ & $\begin{array}{l}673.97 \\
(46.67)\end{array}$ & N/A & $\begin{array}{l}589.04 \\
(34.70)\end{array}$ & Fail to reject $\mathrm{H}_{0}$ \\
\hline Japan-ASEAN & $\begin{array}{l}196.13 \\
(6.35)\end{array}$ & $\begin{array}{l}307.48 \\
(17.63)\end{array}$ & N/A & $\begin{array}{l}454.79 \\
(25.40)\end{array}$ & $\begin{array}{c}\text { Reject } \mathrm{H}_{0} @ 0.1 \% \\
\text { sig. }\end{array}$ \\
\hline South Korea-ASEAN & $\begin{array}{l}77.27 \\
(5.19)\end{array}$ & $\begin{array}{l}241.54 \\
(10.49) \\
\end{array}$ & N/A & $\begin{array}{l}179.17 \\
(14.54) \\
\end{array}$ & $\begin{array}{c}\text { Reject } \mathrm{H}_{0} @ 1 \% \\
\text { sig. }\end{array}$ \\
\hline
\end{tabular}

The actual 'after' coefficients for China and South Korea are above their hypothetical benchmark, whilst Japan's is below. Of these results, the Japanese and South Korean cases are statistically significant. Thus, at 22 degrees of freedom, the $\mathrm{t}$-value of the test for South Korea (3.479) is the only one to exceed the critical t-statistics, doing sufficiently well to pass at the $1 \%$ significance level (2.819). Otherwise expressed, South Korea has outperformed its regional partners in terms of 'relative collaborative growth' (i.e. the growth rate coefficient ratio between the two time periods analysed). Japan, on the other hand, is shown to have relative collaborative growth that is significantly lower than the Plus ThreeASEAN benchmark, passing the relevant t-test at the $0.1 \%$ significance level. Taken together, this evidence effectively discounts the hypothesis that the competitive dynamic between China and Japan has driven the development of the East Asian research community (H2b).

Rather, it seems that there is a case for arguing that South Korea has had the critical effect in this respect, to the extent that its regionally-relevant collaborative research growth is moving it close to displacing Japan from a previously secure 
second position, even in absolute terms (i.e. 241.54 vs. 307.48). This is not to discount the role of China, which has retained and augmented its status as the principal agent of East Asian research growth (its 2010-2015 coefficient being significantly greater than its comparators, at 673.97), although this is perhaps to be expected, owing to its capacity.

\section{(iii) Overarching Comparative Analysis}

It is now possible to draw the fourpart analysis together and consider what it tells us as a whole. It seems clear that there is strong evidence in favour of the Tier 1 hypotheses, but that we should discount the framing of intra-regional interactions indicated by the Tier 2 hypotheses. Nonetheless, the fact that the Tier 1 results are not statistically significant in the case of intra-ASEAN relations, relative to the ASEAN-Asia control, merits further exploration. In this respect, the evidence indicates that the form of higher education regionalisation that is being developed between the 'Plus Three' and core ASEAN nations is, comparatively speaking, stronger than that which has evolved solely within Southeast Asia. Perhaps counterintuitively, then, it would seem that, since the respective commencement of integrative efforts, institutions within the 'Plus Three' have placed a stronger emphasis on collaboration with Southeast Asian institutions (and vice-versa) than this latter grouping has placed on collaboration with each other. In light of this, it is worth reappraising the idea that co-authorship patterns are (in part) being driven by a competitive dynamic. Indeed, it should be acknowledged that, owing to its greater capacity, Northeast Asia is the dominant partner in ASEAN+3 higher education relations. This relative strength in higher education capacity has its basis in the fact that 'higher education and research are central to the global strategies of these nations' (Marginson, 2011, p.596). This national-level policy-drive is evident in the aforementioned Project 211 and Project 985 in China, as well as the 1998 Brain Korea 21 Program (aimed at nurturing globally competitive research universities) and Japan's 2009 Global 30 Project (focused on actively promoting the internationalisation of Japan's top universities). Understood within this context, the fact that Plus Three-ASEAN regionalisation is more pronounced than intra-ASEAN relations may be reflective of the 'Plus Three' actively driving integration, so as to make inroads into the ASEAN market.

If we are to reappraise the concept of collaboration-as-grounded-in-competition, it is necessary to reconsider the principal agents of this dynamic, since the Tier 2 hypotheses were determined to have missed the mark in this respect. In an absolute sense, Malaysia and China have maintained this role within Southeast and Northeast Asia, respectively. However, from the perspective of relative collaborative growth, the most marked shift is seen in South Korea. Accordingly, if one looks outside of the 'Sino-Japanese rivalry' that is perceived to dominate the socio-political landscape of Northeast Asia, it is clear that South Korea has itself 
'been developing and implementing internationalisation policies with the main goal of establishing Korea as an academic centre in East Asian higher education' (Cho \& Palmer, 2013, p.292). The South Korean government's 2007 Strategic Plan for Internationalisation of Higher Education focusses on achieving this through the regional educational hub model, built on partnering with esteemed foreign institutions (McNeill, 2008) and increasing the number of international faculty and students (Gress \& Ilon, 2009). Critically, the wider strategy also sets a 2020 target of South Korea ranking at least $9^{\text {th }}$ worldwide in the number of journal articles published. This paper's analysis indicates that the implementation of these policy objectives is also serving to drive East Asian international co-authorship growth. Thus, we may transition to the Conclusion by asserting that South Korea is rapidly moving to a position of acting as a principal agent for higher education regionalisation within the dominant interface in this respect (i.e. the Plus Three-ASEAN dynamic).

\section{Conclusion}

This paper has analysed the development of higher education regionalisation within East Asia, measured in terms of the level of international co-authorship growth amongst ASEAN+3 nations. The evidence presented indicates the fulfilment of the policy objectives of the AUN and ASEAN+3 UNet, with respect to the development of a research community within Southeast Asia and East Asia, respectively. As this "functional" underpinning of regionalism has been successfully established, it may provide a sufficiently robust platform upon which to build a more thoroughgoing formal framework for higher education integration within East Asia, including 'the establishment of regional institutions related to mobility, quality assurance, and mutual recognition' (Chao Jr., 2014, p.573). Although initial steps have been made in this direction (e.g. ACTS, AUN-QA etc.), when compared to the successes of Bologna, progress has been slow; piecemeal; and typically focussed on Southeast Asia, rather than extended to the wider East Asian region. As this paper has shown, although comparatively recent, efforts to nurture higher education regionalisation in East Asia as a whole have so far been met with success and, consequently, there should (in theory) be no greater practical barrier to achieving formal forms of regionalism at this level, than purely within Southeast Asia. The issue with formal regionalism, of course, is that it is prone to political impediments such as the above referenced SinoJapanese rivalry. However, if regionallyminded policy-makers can build on collaborative efforts such as the ASEAN+3 UNet, as well as the evident micro-level integration demonstrated in this paper, then further integration is certainly realisable.

Returning to the above noted discrepancy between Southeast Asian and East Asian regionalisation, although no direct comparison is possible between the two (owing to the different time periods 
involved), the fact of intra-ASEAN coauthorship growth not achieving statistical significance relative to the 'Asian' control leads to the conclusion that efforts directed at building an East Asian research community have been comparatively more successful than those directed specifically at Southeast Asia. This should represent an important finding for the AUN. In particular, if the achievement of a specifically Southeast Asian research community remains a key objective, then consideration should be given to the success of the South Korean regional education hub model in promoting this and whether elements of this model (such as the article publication target) are directly translatable to the context of the two aspirant education hubs of Malaysia and Singapore.

Nonetheless, a number of limitations should be acknowledged. Firstly, it is worth restating that coauthorship patterns do not necessarily provide an exact map of international research collaboration as a whole ${ }^{4}$ and, as such, appropriate caution should be exercised when considering the generalisability of the analysis to this wider field. Moreover, it is important to note that there are numerous factors influencing co-authorship growth within East Asia other than the collaborative drives initiated by the AUN and ASEAN+3 UNet. In this respect, whilst a large portion of these factors will have been appropriately accounted for in the US and 'Other Asian' controls utilised in the analysis, it is likely that a few of these factors are wholly (or, at least, largely) specific to the East Asia region and have not thereby effectively been controlled for. Although it is beyond the scope of this paper to speculate as to the precise nature of such factors, it would seem likely that the difference between the actual and hypothetical growth rate coefficients within the Tier 1 Analysis are not wholly attributable to an ASEAN effect. That said, although the calculated differentials may be somewhat inflated, the strength of the statistical significance in three of the four cases $(0.1 \%-0.5 \%)$ should be sufficient to allow for the influence of other factors, whilst still showing evidence of an ASEAN effect.

In addition to consideration of these limitations, factors other than research collaboration need to be considered in informing the policy recommendations indicated by this paper and further research is merited in this regard. In particular, there are many other facets to higher education regionalisation (e.g. academic and student exchange programmes), as well as instances of (more complete) forms of higher education regionalism (e.g. Bologna) within which the regionalismregionalisation dynamic can be tested and both represent fertile avenues for future research. The findings of this paper should, therefore, represent a beginning, rather than the end point for research with respect to this interface.

\footnotetext{
${ }^{4}$ See Katz \& Martin (1997) for a detailed exposition of this point.
} 


\section{About The Author}

Oliver Gill obtained his BA in Philosophy \& Politics from The University of Warwick and MA in Philosophy from The Open University. He has since transitioned to specialise in the education field and has obtained an MA in Comparative Education from University College London. His current research focus is principally on education reform movements, studied from both a national and comparative international perspective.

\section{Reference}

ASEAN+3 UNet (2009). Recommendations of the ASEAN+3 Higher Education Policy Dialogue. Retrieved 4 January 2017, from http://www.aunsec.org/policy .php

Asia-Pacific Education Ministers' Meeting (APEM) (2006). The Brisbane Communiqué. Brisbane: APEM.

AUN (2017). History and Background. Retrieved 4 January 2017, from http://www.aunsec.org/ourhistory .php

Beeson, M. (2003). ASEAN Plus Three and the Rise of Reactionary Regionalism. Contemporary Southeast Asia, 25(2), 251268.

Campanini, A. (2015). Bologna Process. In J.D. Wright (Ed.), International Encyclopedia of the Social \& Behavioural Sciences ( $2^{\text {nd }}$ ed.) (pp.741-746). Oxford: Elsevier.
Chan, S. (2012). Shifting Patterns of Student Mobility in Asia. Higher Education Policy, 25(2), 207-224.

Chao Jr., R.Y. (2011). Reflections on the Bologna Process: the making of an Asia Pacific Higher Education Area. European Journal of Higher Education, 1(2-3), 102-118.

Chao Jr., R.Y. (2014). Pathways to an East Asian Higher Education Area: a comparative analysis of East Asian and European regionalisation processes. Higher Education, 68(4), 559575.

Cho, Y.H., \& Palmer, J.D. (2013). Stakeholders' views of South Korea's higher education internationalisation policy. Higher Education, 65(3), 291-308.

Clark, N. (2012). Understanding Transnational Education, Its Growth and Implications. World Education News and Reviews. Retrieved 21 January 2017, from http://wenr.wes.org/2012/08/wenr-aug ust-2012-understanding-transnationale ducation-its-growth-and-implications

Cummings, W.K. (2014). Asian Research: The Role of Universities. In A. Yonezawa, Y. Kitamura, A. Meerman, \& K. Kuroda (Eds.), Emerging International Dimensions in East Asian Higher Education (pp.35-54). London: Springer.

EURYDICE (2009). Higher Education in Europe 2009: Developments in the Bologna Process. Brussels: EURYDICE. 
Feuer, H.N., \& Hornidge, A. (2015). Higher Education cooperation in ASEAN: building towards integration or manufacturing consent? Comparative Education, 51(3), 327-352.

Gress, D.R., \& Ilon, L. (2009). Successful integration of foreign faculty into Korean universities: A proposed framework. KEDI Journal of Educational Policy, 6(2), 183-204.

Hawkins, J.N. (2012). Regionalisation and harmonisation of higher education in Asia. Asian Education and Development Studies, 1(1), 96-108.

Hidetaka, Y. (2005). Political Leadership, Informality, and Regional Integration in East Asia: The Evolution of ASEAN Plus Three. European Journal of East Asian Studies, 4(2), 205-232.

Huisman, J., Adelman, C., Hsieh, C., Shams, F., \& Wilkins, S. (2012). Europe's Bologna Process and its Impact on Global Higher Education. In D.K. Deardorff, H. de Wit, J.D. Heyl, \& T. Adams (Eds.), The SAGE Handbook of International Higher Education (pp.81100). Thousand Oaks: SAGE.

Hund, M. (2003). ASEAN Plus Three: towards a new age of pan-East Asian regionalism? A skeptic's appraisal. The Pacific Review, 16(3), 383-417.

Iammarino, S., \& Archibugi, D. (2005). Atlantic interdependent knowledgebased economies. In G. Boyd, A.M. Rugman, \& P.C. Padoan (Eds.), European-American Trade and Financial
Alliances (pp.24-51). Cheltenham: Edward Elgar.

Jung, J. (2012). International Research Collaboration among Academics in China and South Korea. International Journal of Chinese Education, 1(2), 235254.

Katz, J.S., \& Martin, B.R. (1997). What is research collaboration? Research Policy, 26(1), 1-18.

Knight, J. (2012). A Conceptual Framework for the Regionalisation of Higher education: Application to Asia. In J.N. Hawkins, K.M. Mok, \& D.E. Neubauer (Eds.), Higher Education Regionalisation in Asia Pacific: implications for governance, citizenship and university transformation (pp.17-35). Basingstoke: Palgrave Macmillan.

Knight, J. (2013). A Model for the Regionalisation of Higher Education: The Role and Contribution of Tuning. Tuning Journal of Higher Education, 1(1), 1-12.

Kuroda, K., \& Passarelli, D. (2009). Modelling TNE Directions in Asia. London: The Observatory on Borderless Higher Education.

Kuroda, K., Yuki, T., \& Kang, K. (2010). Cross-Border Higher Education for Regional Integration: Analysis of the JICA-RI Survey on Leading Universities in East Asia. Tokyo: JICA Research Institute.

Li, M., \& Chen, Q. (2011). Globalisation, internationalisation and the world- 
class university movement: the China experience. In R. King, S. Marginson, \& R. Naidoo (Eds.), Handbook on Globalisation and Higher Education (pp.241-255). Cheltenham: Edward Elgar.

Marginson, S. (2011). Higher education in East Asia and Singapore: rise of the Confucian Model. Higher Education, 61(5), 587-611

McNeill, D. (2008). South Korea Seeks a New Role as a Higher-Education Hub. Chronicle of Higher Education, 54(28), A1.

Mok, K.H. (2011). Regional responses to globalisation challenges: the assertion of soft power and changing university governance in Singapore, Hong Kong and Malaysia. In R. King, S. Marginson, \& R. Naidoo (Eds.), Handbook on Globalisation and Higher Education (pp.179-196). Cheltenham: Edward Elgar.

Mustajarvi, J., \& Bouchon, F. (2014). Tourism Education and Regional Integration: Is the European Union (EU) Model Applicable for ASEAN? Asia-Pacific Journal of Innovation in Hospitality and Tourism, 3(2), 215-237.

National Science Board (2016). Science and Engineering Indicators 2016. Arlington: National Science Foundation.

Rattanasevee, P. (2014). Towards institutionalised regionalism: the role of institutions and prospects for institutionalisation in ASEAN. SpringerPlus, 3(1), 1-10.
Rich, D. (2010). The Bologna Process in European Higher Education. In P. Peterson, E. Baker, \& B. McGaw (Eds.), International Encyclopedia of Education (3 ${ }^{\text {rd }}$ Edition) (pp.566-572). Oxford: Elsevier.

Savage, V.R. (2011). Problems of tertiary education and regional academic journals: A view from Southeast Asia. Asia Pacific Viewpoint, 52(2), 219-227.

SEAMEO RIHED (2009). Raising Awareness: Exploring the Ideas of Creating a Common Space in Higher Education in Southeast Asia. Bangkok: SEAMEO RIHED.

Stubbs, R. (2002). ASEAN Plus Three: Emerging East Asian Regionalism? Asian Survey, 42(3), 440-455.

Sugimura, M. (2012a). Possibility of East Asian integration through the regional networks and universities' cooperation in higher education. Asian Education and Development Studies, 1(1), 85-95.

Sugimura, M. (2012b). The Function of Regional Networks in East Asian Higher Education. In J.N. Hawkins, K.H. Mok, \& D.E. Neubauer (Eds.), Higher Education Regionalisation in Asia Pacific: implications for governance, citizenship and university transformation (pp.45-64). Basingstoke: Palgrave Macmillan.

Umemiya, N. (2008). Regional Quality Assurance Activity in Higher Education in Southeast Asia: Its Characteristics and Driving Forces. 
Quality in Higher Education, 14(3), 277290.

UNESCO Institute for Statistics (2010). Inbound Internationally Mobile Students by Region of Origin. Retrieved 22 January 2017, from http://uis.unesco.org/indicator/edu-mo bility-in-region

Vögtle, E.M., \& Martens, K. (2014). The Bologna Process as a template for transnational policy coordination. Policy Studies, 35(3), 246-263.

Wagner, C.S., Park, H.W., \& Leydesdorff, L. (2015). The Continuing Growth of Global Cooperation Networks in Research: A Conundrum for National Governments. PLoS ONE, 10(7), 1-15.

Westerheijden, D.F., Beerkens, E., Cremonini, L., Huisman, J., Kehm, B., Kovač, A., Lažetić, P., McCoshan, A., Muzuraityte, N., Souto Otero, M., de Weert, E., Witte, J., \& Yağci, Y. (2010). The first decade of working on the European Higher Education Area: Bologna Process independent assessment (Vol. 1). Enschede: Center for Higher Education Policy Studies.

Yang, R. (2012). Internationalisation, Regionalisation, and Soft Power: China's Relations with ASEAN Member Countries in Higher Education. Frontiers of Education in China, 7(4), 486-507.

Yap, J.T. (2012). Regional Cooperation in Education: Issues for Developing Countries in the Asia-Pacific. Makati
City: Philippine Institute for Development Studies.

Yavaprabhas, S. (2014). The Harmonisation of Higher Education in Southeast Asia. In A. Yonezawa, Y. Kitamura, A. Meerman, \& K. Kuroda (Eds.), Emerging International Dimensions in East Asian Higher Education (pp.81-102). London: Springer.

Yonezawa, A., Horta, H., \& Osawa, A. (2016). Mobility, formation and development of the academic profession in science, technology, engineering and mathematics in East and South East Asia. Comparative Education, 52(1), 44-61.

Zeng, Q., Adams, J., \& Gibbs, A. (2013). Are China and the ASEAN ready for a Bologna Process? - Factors affecting the establishment of the ChinaASEAN higher education area. Educational Review, 65(3), 321-341. 


\section{Appendix 1 - Model Formulae (Tier 1)}

\section{Hypothesis:}

$H_{0}: B_{1}=B_{1}^{0}$

$$
H_{1}: B_{1}>B_{1}^{0}
$$

\section{Hypothesis Test:}

The test statistic is

$$
t=\frac{B_{1}-B_{1}^{0}}{\sqrt{ }\left(s_{b_{1}}^{2}+s_{b_{1}^{0}}^{2}\right)} \sim T\left(n_{1}+n_{1}^{0}-2\right)
$$

Where $B_{1}$ is the intra-ASEAN / APT$\operatorname{ASEAN}\left(t_{2}\right)$ slope coefficient and

$$
B_{1}^{0}=R\left(B_{2}\right)
$$

Where $B_{2}$ is the intra-ASEAN / APTASEAN $\left(t_{1}\right)$ slope coefficient and

$$
R=\frac{B_{3}}{B_{4}}
$$

Where $B_{3}$ is the ASEAN-Asia/US / APTAsia/US $\left(t_{2}\right)$ slope coefficient and $B_{4}$ is the ASEAN-Asia/US / APT-Asia/US ( $\left.t_{1}\right)$ slope coefficient.

Consequently

$$
\begin{gathered}
n_{1}^{0}=n_{2}+n_{3}+n_{4}-6 \\
\text { and } \\
s_{b_{1}^{0}}=B_{1}^{0}\left[\sqrt{ }\left[\left(\frac{s_{r}}{R}\right)^{2}+\left(\frac{s_{b_{2}}}{B_{2}}\right)^{2}\right]\right]
\end{gathered}
$$

Where

$$
s_{r}=R\left[\sqrt{ }\left[\left(\frac{s_{b_{3}}}{B_{3}}\right)^{2}+\left(\frac{s_{b_{4}}}{B_{4}}\right)^{2}\right]\right]
$$

\section{Appendix 1 - Model Formulae (Tier 2)}

\section{Hypothesis:}

$H_{0}: B_{1}=B_{1}^{0}$

$$
H_{1}: B_{1}>B_{1}^{0}
$$

\section{Hypothesis Test:}

The test statistic is

$$
t=\frac{B_{1}-B_{1}^{0}}{\sqrt{ }\left(s_{b_{1}}^{2}+s_{b_{1}^{0}}^{2}\right)} \sim T\left(n_{1}+n_{1}^{0}-2\right)
$$

Where $B_{1}$ is the country-ASEAN $\left(t_{2}\right)$ slope coefficient and

$$
B_{1}^{0}=R\left(B_{2}\right)
$$

Where $B_{2}$ is the country-ASEAN $\left(t_{1}\right)$ slope coefficient and

$$
R=\frac{B_{3}}{B_{4}}
$$

Where $B_{3}$ is the intra-ASEAN / APTASEAN $\left(t_{2}\right)$ slope coefficient and $B_{4}$ is the intra-ASEAN / APT-ASEAN $\left(t_{1}\right)$ slope coefficient.

Consequently

$$
\begin{gathered}
n_{1}^{0}=n_{2}+n_{3}+n_{4}-6 \\
\text { and } \\
s_{b_{1}^{0}}=B_{1}^{0}\left[\sqrt{ }\left[\left(\frac{s_{r}}{R}\right)^{2}+\left(\frac{s_{b_{2}}}{B_{2}}\right)^{2}\right]\right]
\end{gathered}
$$

Where

$$
s_{r}=R\left[\sqrt{ }\left[\left(\frac{s_{b_{3}}}{B_{3}}\right)^{2}+\left(\frac{s_{b_{4}}}{B_{4}}\right)^{2}\right]\right]
$$

